Original Research Paper

\title{
Urban Renewal through Sustainable Development: A Case Study in Iran
}

\author{
${ }^{1}$ S. Hessam Miri, ${ }^{2}$ S. Behnam Miri and ${ }^{3}$ Mohammad Rasoul Maghsoudi \\ ${ }^{1}$ Master of Urban Design, University of Guilan, Rasht, Iran \\ ${ }^{2}$ Bachelor of Urban Planning, University of Guilan, Rasht, Iran \\ ${ }^{3}$ Master of Architecture, Islamic Azad University of Chaloos, Chaloos, Iran
}

Article history

Received: 05-07-2019

Revised: 04-10-2019

Accepted: 08-01-2020

Corresponding Author:

S. Hessam Miri

Master of Urban Design,

University of Guilan, Rasht,

Iran

Email: hessam.miri@gmail.com.

\begin{abstract}
Decayed urban areas, especially those located in the city center, are one of the major problems of cities. These areas, which known as the main nucleus of cities at the time of their emergence, have lost their previous prosperity and importance due to several reasons such as the deterioration of their properties, the immigration of their original residents and the development of the city in other areas. They are mostly old neighborhoods where the middle and low classes of the society live together. In this paper, we aim to examine the problems of urban blight in the Bagherabad neighborhood, Rasht, Iran, from the sustainability perspective and provide it with a renewal plan. Bagherabad is a decayed urban neighborhood facing with serious physical, social, cultural, environmental and economic problems. Not only have these issues affected this neighborhood and its inhabitants, but they also have spread to its neighboring areas. To mitigate the adverse effects of these issues, we propose a restoration plan with a substantial focus on elevating social qualities such as vitality, dynamism, identity, social interactions and security. For this purpose, based on the field surveys, questionnaires and interviews with a considerable number of residents, we collect the required information about the existing issues in the neighborhood. Then, we propose a sustainable plan using descriptive methods, expertise knowledge and experiences have gained from the implementation of renewal plans in other regions.
\end{abstract}

Keywords: Sustainable Development, Urban Decay, Urban Renewal, Urban Planning

\section{Introduction}

In recent decades, urban decay has exacerbated many urban problems in Iran. It affects all aspects of cities, reduces urban quality of life and leads to instability (Shoja and Heidari, 2015). Urban decay causes several social, physical, environmental and economic problems such as the inefficiency of urban physical structure and infrastructures, the reduction of land price and property value, the aggravation of social and cultural anomalies, the intensification of environmental pollutions and the destruction of natural resources (Andersen, 2003).

Most developed and developing countries have faced with unpleasant urban problems resulted from desolated urban neighborhoods. These neighborhoods were initially found in the oldest urban areas with a very low quality of housing. In some cities of Iran, they have also emerged in newer housing estates outside the city center since the beginning of the 1990s. These neighborhoods affect visual physical and ecological aspects of the city and considerably decrease the attractiveness of urban landscapes. They are often recognized by the public as places that are less inhabited or occupied by poor people; therefore, they are called as 'places of low-class community' (Farjam and Hossieni Motlaq, 2019).

After the industrial revolution, urbanization resulted in appearance of mega cities around the world. Nowadays, urban development is growing so rapidly that it seems to make the earth as an urban world. However, the negative effects of urban lifestyle have made major problems for the environment and human beings. This is why the sustainable development has been put in the 
agenda of many institutions, organizations and governments. Recent studies on sustainable development have attempted to introduce its features and proposed some solutions to achieve this type of development. Nevertheless, issues related to urban sustainable development have been rarely taken into attention (Yigitcanlar and Teriman, 2015). The sustainable development has been proposed to protect natural resources besides considering social and economic benefits. In other words, through sustainable urban development, urban planners and decision makers attempt to improve the urban physical structure and environmental conditions in order to meet the basic social, economic and cultural needs of citizens (Moroke et al., 2019). As a result, the city is environmentally sustainable, economically viable and socially equal. According to this view, although physical, economic, social and environmental restoration are interacting with each other, economic recovery can be regarded as an operational aspect and a guarantor of physical and social rehabilitation Peres Almeida et al. (2018). However, it should not overcome the preservation of historical, social and traditional characteristics of cities. In this regard, the attention to the limited economic capacity of decayed areas is very important to increase prosperity. Therefore, a sustainable development should be found in the form of planned strategies with the aim of preserving the historical, cultural, social and environmental aspects of cities Danladi et al. (2018).

Due to the rapid and unrestrained urbanization changes, many big cities of Iran have faced with serious economic, social and cultural issues. One of these cities is Rasht, located in the north of Iran, whose central ancient area, Bagherabad neighborhood, has confronted with severe urban problems and lost its past attraction. Therefore, the goal of this study is to identify the major problems resulted from urban decay in the Bagherabad neighborhood as well as to propose a comprehensive urban development plan to improve this area from the perspective of sustainable development. To achieve this goal, several robust solutions are considered for renovating decayed areas, preserving historical places and monuments, rehabilitating social, cultural and economic activities and protecting the environment. In other words, this study explores the most important indicators of sustainable development for urban renewal, where there is rare research have been conducted on. For this purpose, several environmental, social, cultural and economic indicators are considered to propose a sustainable urban development plan for dealing with urban decay in the Bagherabad neighborhood, Rasht, Iran, as a case study. The study also helps urban planners and decision makers better understand the issues that people face in old urban areas and mitigate these issues from the sustainable urban development perspective. The results of this study could be generalized to other northern regions of Iran as well as of the world (Ghesmi et al., 2017).

\section{Research Background}

The first steps towards restoring decayed urban areas should be sought in Western Europe, especially in France and England Carley and Christie (2017), following the industrial revolution in the years of 1760-1830 and its subsequent urbanization. Indeed, the history of urban rehabilitation is more than 200 years in these Countries.

There are some studies that have examined urban decay and suggested various solutions to mitigate its negative impacts. Mutisya (2016) examined urban decay and its physical, social and economic consequences in Nairobi. He found that in addition to physical and economic problems, there was also a lack of collective participation among residents and city administrators to rehabilitate this area. To cope with these problems and improve the area, he proposed renovation and restoration methods from the perspective of sustainable development. Li et al. (2009) showed that sustainable urban development is the result of a comprehensive plan containing ecological planning, construction management and urban planning. Considering the city of Jining as a case study, they identified 52 sustainability indicators leading to a sustainable development in various aspects of the city including the economics, ecosystem, urban infrastructures and quality of life. They proposed a comprehensive plan to achieve a sustainable city over the next two decades through the evaluation of the sustainability indicators in different periods.

One of the most important components of sustainable urban development is land use and transportation planning. Many studies have proposed robust approaches for integrated land use and transportation planning to move toward urban sustainability. Shirzadi Babakan and Alimohammadi (2016), Babakan and Taleai (2015) and Shirzadi Babakan et al. (2015) developed a novel agentbased approach for the microsimulation of households' behavior in choosing their residential location, one of the key parts of urban land use and transportation planning. To this end, they considered a comprehensive set of criteria including demographic and socioeconomic characteristics of households, accessibility to various urban facilities, distance from workplace, housing rent and air and noise pollutions. They implemented their proposed approach in Tehran, the capital of Iran, as a case study and obtained reliable and highly accurate results.

Shirzadi et al. (2013) made a sustainable urban transport plan for an urban corridor in Tehran using the combination of the Analytic Network Process (ANP) and the Technique for Order of Preference by Similarity to Ideal Solution (TOPSIS). Considering twenty indicators 
were categorized into seven main criteria of operating cost, travel time, safety, reliability, flexibility, environmental pollutions and transport mode properties, they evaluate the effectiveness and efficiency of four public transport modes including subway, BRT, bus and taxi. They demonstrated the capability of multi-criteria decision making methods for sustainable urban transportation planning. Azari and Shirzadi Babakan (2016) developed a sustainable plan for urban expansion in the city of Baghmalek, Iran, using a combination of Analytical Hierarchy Processes (AHP) and Geographic Information System (GIS). They considered twelve indicators under five general categories of climatic, topographic, geological, soil and Land-Use/Land-Cover (LULC) characteristics to find appropriate locations for the sustainable development of urban built environment. Karimi et al. (2019) proposed a novel Support Vector Machine (SVM) model to predict LULC change and urban expansion in Guilford County, North Carolina. They applied several data sampling strategies and various con Figurations of SVM to obtain high accuracy, reliability and predictability in LULC modeling. Their model remarkably improved the prediction accuracy of urban expansion; hence, it would considerably help urban planners and decision makers propose sustainable plans for developing urban built areas as well as effective policies for mitigating the negative effects of urbanization on other urban elements.

\section{Study Area}

Rasht, one of the big cities of Iran located in Guilan, north of Iran, faces with serious urban problems such as urban decay, inefficiency of public transit and the lack of proper distribution of social, cultural and economic activities. Bagherabad is one of the most important neighborhoods of Rasht from the past to the present because it is located at the heart of the city and includes a majority of commercial activities. This neighborhood contains a number of historical caravansaries that have been left unused and degraded and have led to unfavorable physical conditions in this neighborhood. Bagherabad, as the primary nucleus of Rasht, is one of the areas where urban decay is widely seen. The main reasons of physical, social and economic issues in this neighborhood are the lack of vitality, dynamism, readability, diversity, permeability, social interaction, control and supervision and enrichment. In other words, Inadequate living conditions, lack of proper activities to meet daily needs, lack of appropriate access to urban facilities and the inconsistency in the physical structure have exacerbated the existing conditions. Figure 1 shows the geographic location of the study area.

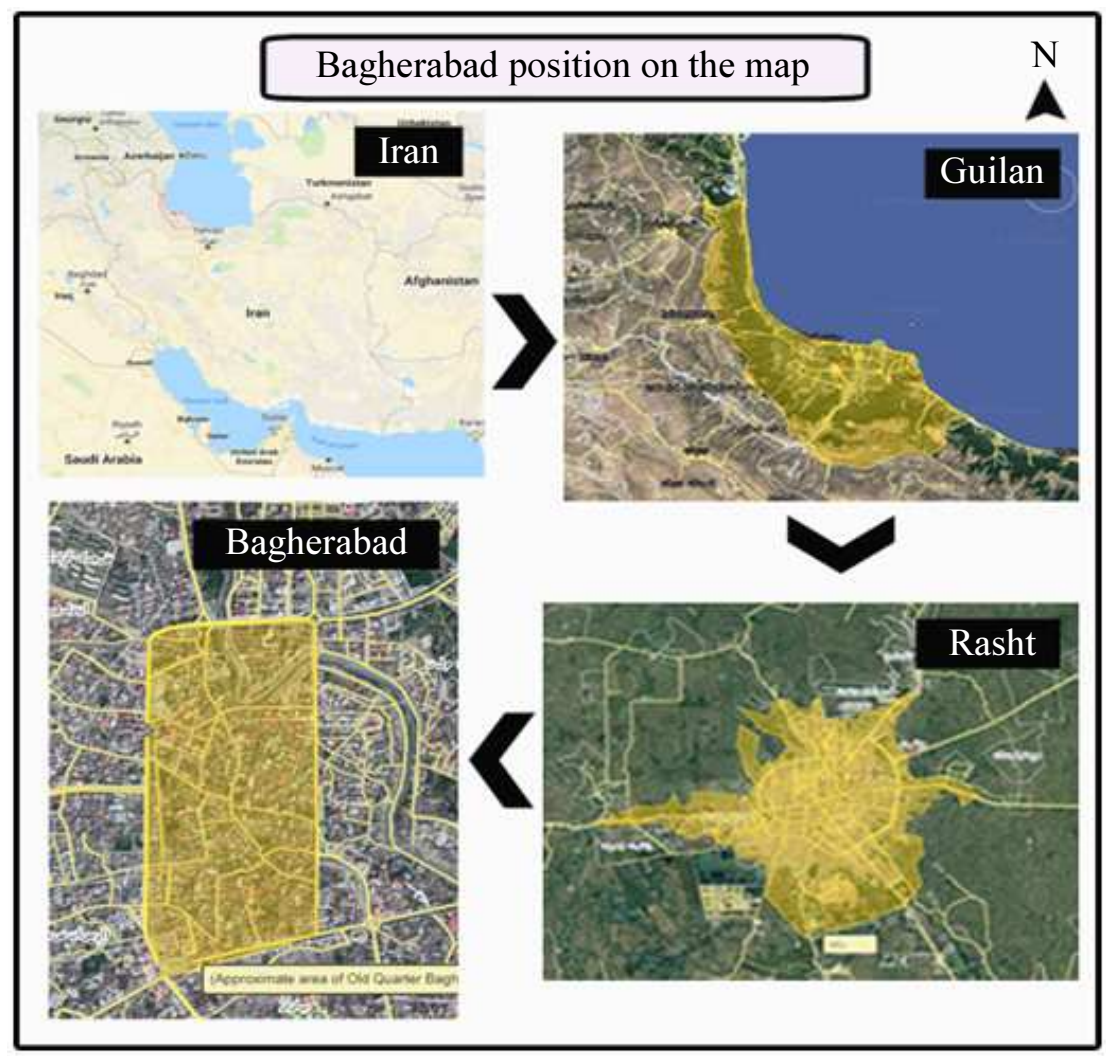

Fig. 1: The geographic location of the study area 


\section{Methodology}

This study Conducted in Bagheraabad neighborhood in the Core Zone of Rasht, Iran. It produced with a questionnaire survey that was used and given to the local community (all the households) between the years of 2012-2014 for getting a good point of view of the zone and after gathering the needed data form the survey and presenting it to the experts for getting their opinion to achieving a conclusion in reaching the quality of life and developing the area.

We have considered several robust solutions for renovating decayed areas, preserving historical places and monuments, rehabilitating social, cultural and economic activities and protecting the environment to achieve this goal (Mahmoud, 2017; Pobric and Robinson, 2019).

In other words, this study explores the most important indicators of sustainable development for urban renewal. For this purpose, several environmental, social, cultural and economic indicators are considered to propose a sustainable urban development plan for dealing with urban decay in the Bagherabad neighborhood, Rasht, Iran, as a case study. The study also helps urban planners and decision-makers better understand the issues that people face in old urban areas and mitigate these issues from the sustainable urban development perspective. The results of this study could be generalized to other northern regions of Iran as well as of the world.

This research employs a qualitative methodological approach to investigate the problems and achieving the objectives. a mixed research method including an in-depth review of the relevant literature as well as semi-structured interviews and face-to-face questionnaires are adopted for this study (Matsuoka Rodney and Kaplan, 2008; Illia Ibrahim et al., 2017).
The questionnaire included questions about fabric quality, people's economics, social spaces and environmental quality. it was designed with the help of experts in all mentioned areas. The data itself contains smaller indices that helped us understand the underlying criteria. After the data collection, we obtained general results using the average method (good-average-poor degrees) and for better understanding changed it to a percentage model. Equation 1 shows the average method formula for Fig. 2 (Pourahmad et al., 2014):

$\frac{\text { good }}{(\text { good }+ \text { average }+ \text { poor })} \times 100$

We did this for average and poor, too. Then by using them, we came up with a comprehensive diagram for planning decisions and final plans. Analysis of existing per capita and future needs of the community was also used to present the proposed plan.

We also used SWOT analysis model to identify the strength, weakness, opportunities and threats based on the opinions of experts and people and personal observations in the neighborhood (Table 3).

To analyze the data and achieve a well-designed plan, the macro objectives (macro goals) and sub-objectives (micro goals) have been identified.

\section{Goals of the Sustainable Urban Development Plan}

To achieve a sustainable urban development, four general goals including physical, economic, sociocultural and environmental improvements are considered in this study (Table 1). As presented in Table 1, each general goal contains several micro goals.

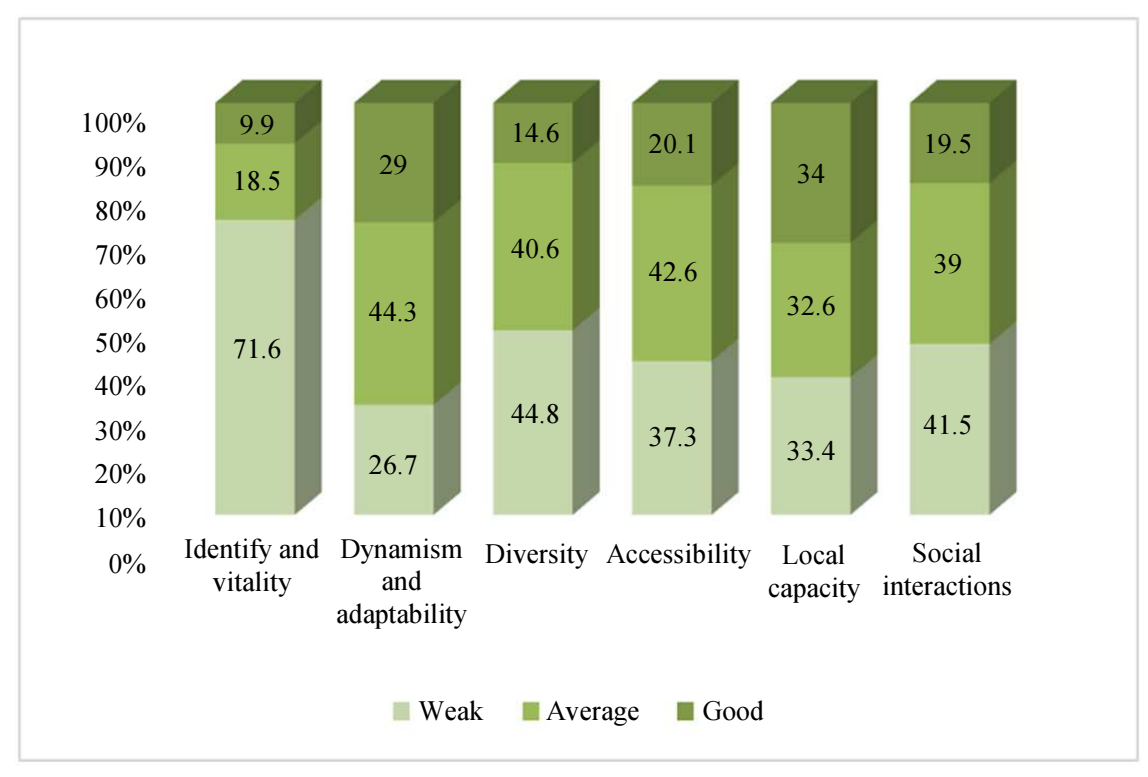

Fig. 2: The level of sustainability indicators in the study area 


\section{Policies of the Sustainable Urban Development Plan}

According to other researches in the field of sustainable development elsewhere in the world and citing them with the methods they have used renovating urban decay and achieving a sustainable urban development plan, the following policies are considered (Moroke et al., 2019):

1. Elimination of incompatible activities from the historical zone

2. Architectural organization of facades

3. Reinforcement and renovation of buildings

4. Providing financial resources to improve the local economy
5. Improvement of the internal accessibility with the focus on walkability

6. Improvement of the external accessibility to public transportation systems

7. Development of green and recreational spaces

\section{Indicators of the Sustainable Urban Development Plan}

There are various criteria and indicators developed to evaluate urban sustainability. In this study, the most common urban sustainability criteria including urban identity and vitality, dynamism and adaptability, accessibility, diversity, local capacity and social interactions are used to make a sustainable urban development plan for renovation of decayed areas in Bagherabad neighborhood, Rasht, Iran (Table 2).

Table 1: Macro and micro goals for urban renewal from the sustainable development perspective

\begin{tabular}{ll}
\hline Macro goal & Micro goal \\
\hline Physical improvement (Frantzeskaki, 2019) & Promotion of safety and construction standards \\
& Development of modern technology \\
Elevation of urban identity & Development of district-based renovation \\
Socio-cultural improvement (Kagan et al., 2018) & Supply of urban infrastructures \\
& Enhancement of community participation \\
Economic improvement (Nilsson et al., 2016) & Reduction of social class difference \\
& Improvement of social security \\
Environmental improvement (Frantzeskaki, 2019) & Development of the local economy \\
& Enhancement of residents' economic well-being \\
& Attraction of private and public investments \\
& Reduction of environmental pollutions \\
& Development of green space \\
& Prevention of littering in abandoned lands \\
\hline
\end{tabular}

Table 2: Criteria and indicators of the sustainable urban development plan

\begin{tabular}{ll}
\hline Criteria & Indicators \\
\hline Urban identity and vitality (Barton et al., 2003) & Convenient spaces for pedestrians \\
& Smooth traffic \\
& Local shopping centers \\
& Local recreational areas \\
& Local cultural centers \\
Dynamism and adaptability (Wheeler, 2004) & Active urban life \\
& Distribution of open spaces and transit networks \\
& Use of indigenous construction materials \\
Diversity (Chapman, 2004) & Variety in housing ownership \\
& Diversity in demographic characteristics \\
& Diversity in social and cultural activities \\
Accessibility (Chapman, 2004) & Diversity in economic activities \\
& Diversity in environmental characteristics \\
Local capacity (Chapman, 2004) & Accessibility to various local and regional activities \\
& Accessibility to urban facilities \\
& Accessibility to street network and public transit \\
& Development capacity \\
Social interactions (Wheeler, 2004) & Availability and adequacy of local resources \\
& Security and safety \\
& Local potential for reduction of environmental pollutions \\
\hline
\end{tabular}




\begin{tabular}{|c|c|c|c|c|}
\hline & Strength & weakness & opportunity & Threat \\
\hline $\begin{array}{l}\text { Urban identity } \\
\text { and vitality }\end{array}$ & $\begin{array}{l}\text { existence of Samadkhan Jame } \\
\text { Mosque in the neighbourhood. } \\
\text { There are urban facades that } \\
\text { inspires the construction of } \\
\text { new buildings. }\end{array}$ & $\begin{array}{l}\text { pollution in andalongside the } \\
\text { river in all the neighbourhood. } \\
\text { existence of abandoned } \\
\text { buildings. }\end{array}$ & $\begin{array}{l}\text { Use the river edges for } \\
\text { recreational activities. Existence } \\
\text { of the karvensaras that left } \\
\text { unused. }\end{array}$ & $\begin{array}{l}\text { Existence of incompatible } \\
\text { activities. Lack of flexible } \\
\text { spaces. }\end{array}$ \\
\hline $\begin{array}{l}\text { Dynamism and } \\
\text { adaptability }\end{array}$ & $\begin{array}{l}\text { Existence of Open spaces. } \\
\text { Existence of activities in the } \\
\text { edge of neighborhood. }\end{array}$ & $\begin{array}{l}\text { Lack of appropriate activities in } \\
\text { the center to meet needs. } \\
\text { Inadequacy of the building and } \\
\text { its activities. }\end{array}$ & $\begin{array}{l}\text { Suitable open spaces for changing } \\
\text { to gree nspaces. Demolished } \\
\text { buildings with the potential to } \\
\text { become needs-compatible } \\
\text { activates. }\end{array}$ & $\begin{array}{l}\text { Lack of sidewalks in the } \\
\text { streets. Lack of } \\
\text { compatibility of building } \\
\text { facades and activities. }\end{array}$ \\
\hline Diversity & $\begin{array}{l}\text { High activity diversity at the } \\
\text { edges. Existence of diversity } \\
\text { as well as integration in } \\
\text { urban facades. }\end{array}$ & $\begin{array}{l}\text { Lack of functional diversity in } \\
\text { the neighbourhood. The look of } \\
\text { the new buildings are the same. }\end{array}$ & $\begin{array}{l}\text { Using the river to create a variety } \\
\text { of activities. Use abandoned } \\
\text { spaces to create diverse activities. }\end{array}$ & $\begin{array}{l}\text { Abandoning activities, spaces } \\
\text { and buildings. Existence of } \\
\text { too many incompatible } \\
\text { activities alongside each } \\
\text { other. }\end{array}$ \\
\hline Accessibility & $\begin{array}{l}\text { Easy access to the } \\
\text { neighborhood center. existence } \\
\text { of inviting edges in old parts. }\end{array}$ & $\begin{array}{l}\text { The passages are polluted. } \\
\text { unsuitable access to activities } \\
\text { in some areas. }\end{array}$ & $\begin{array}{l}\text { There are narrow passages that } \\
\text { can be widened. Using the } \\
\text { river's edge as a place for people } \\
\text { to spend time. }\end{array}$ & $\begin{array}{l}\text { The existence of narrow } \\
\text { passages that disrupt } \\
\text { assistance in time of need. } \\
\text { Narrow passageways with } \\
\text { ruined facades. }\end{array}$ \\
\hline Local capacity & $\begin{array}{l}\text { Empty green and open spaces. } \\
\text { Lying between four important } \\
\text { streets. }\end{array}$ & $\begin{array}{l}\text { Lack of proper parking spaces } \\
\text { for cars. Lack of proper lighting } \\
\text { at night. }\end{array}$ & $\begin{array}{l}\text { Existence of Semi-active } \\
\text { activities. Using native } \\
\text { architecture to build new spaces. }\end{array}$ & $\begin{array}{l}\text { The loss of aquatic life in the } \\
\text { river because of the } \\
\text { pollution. Irregular building } \\
\text { construction in some parts. }\end{array}$ \\
\hline $\begin{array}{l}\text { Social } \\
\text { interactions }\end{array}$ & $\begin{array}{l}\text { semi-convenient social } \\
\text { interactions in some parts. } \\
\text { existence of samadkhan } \\
\text { Mosque in the center. }\end{array}$ & $\begin{array}{l}\text { Lack of proper spaces for public } \\
\text { gatherings. lack of suitable } \\
\text { spaces for people interaction. }\end{array}$ & $\begin{array}{l}\text { existence of Empty spaces in } \\
\text { order to change to change to } \\
\text { parks for social interaction. } \\
\text { Using residents to participate }\end{array}$ & $\begin{array}{l}\text { Lack of suitable spaces on } \\
\text { the sidewalks for pedestrians } \\
\text { to interact. existence of in } \\
\text { projects. Defenseless and } \\
\text { unsafe spaces. }\end{array}$ \\
\hline
\end{tabular}

\section{Implementation and Results}

\section{Analysis of Sustainable Development Indicators}

As we can see, we achieve the following graph based on the data extracted from the neighborhood and the analysis of it by the experts and the descriptions that have been mentioned above on how we achieved these numbers on the methodology section.

There is not a definite urban identity and vitality in the Bagherabad neighborhood; the only urban identity element is an ancient mosque, located at the center and acts as the main symbol of the neighborhood. Due to inadequate space for walking, heavy traffic, the shortage of retail stores and the lack of appropriate recreational spaces, Liveliness in the neighborhood is very low.

Consequently, the residents of the neighborhood have to travel outside the neighborhood to meet their basic needs that would considerably reduce the adaptability of the neighborhood.

Demographic and socio-cultural diversities are high in the neighborhood. While a majority of indigenous residents of the neighborhood have moved out, non-native immigrants compose the main part of residents leading to socio-cultural diversity. Economic diversity has significant effects both on neighborhood activities and residents' livelihood. The local economy of the neighborhood meaningfully changes from high to low levels by moving from the north to the southern parts of the neighborhood.
Because of the substantial cultural differences, the level of residents' participation in urban activities is different. Although residents tend to participate in various activities for improving the living conditions in the neighborhood, a strong collaboration among urban organizations and also appropriate financial resources are required for implementing an urban renewal plan in the neighborhood. Figure 2 shows the level of sustainability in the study area with respect to various indicators. As seen in this Figure the Bagherabad neighborhood has serious physical, social and economic problems.

We also have achieved a SWOT table that would help us to face properly with this kind of situation. We have used the experiences of others who have used this method to do their research.

SWOT analysis (or SWOT matrix) is a strategic planning technique used to help a person or organization identify strengths, weaknesses, opportunities and threats related to project planning. Cui et al. (2019) It is intended to specify the objectives of the business venture or project and identify the internal and external factors that are favorable and unfavorable to achieving those objectives. Users of a SWOT analysis often ask and answer questions to generate meaningful information for each category to make the tool useful and identify their competitive advantage (Dyson, 2004).

Halla (2007) has done a SWOT analysis regarding the urban management approach using the case of 
Dares Salaam City in Tanzania. Participant observation and documentary reviews have been adopted in capturing and analyzing the available data. The main findings lead to a conclusion that the urban management approach is stronger than the procedural or master-planning approach in planning and managing cities, generally and planning and managing Dar es Salaam City, specifically.

Hatefi (2018) also identified the strengths and weaknesses as well as the opportunities and threats of Shahrkord transportation system using (SWOT) analysis. his results show that Shahrekord's transportation system holds a conservative situation.

Khalifipour et al. (2012) also done SWOT analysis matrix regarding the urban management approach for Isfahan City in Iran. Based on his findings the Location of city in country, Rich cultural history and civilization, the presence of Zayanderood river in Isfahan are the most strengths factors which can make great opportunities for tourist attractions, however the high rate of urban expansion and industrial development, etc. be considered as weaknesses and threats for strategic environmental planning.

\section{The Proposed Land-Use Plan}

The proposed scheme has been used concerning the work done and previous experiences close to this research such as Navab Regeneration Project in Central Tehran (Bahrainy and Aminzadeh, 2007) and gentrification and urban regeneration in Glasgow Botti (2013). which are similar in terms of the present situation as well as the manner of dealing.

The proposed plan has been seen due to deficiencies in the neighborhood. As we can see in the table below, these suggestions are made in light of the shortage of space required in all fields (like green spaces, welfare of people, economic, physical and environmental) as well as using the dependency and independency matrix and standards available in Iran. The proposed land-use plan has been done using GIS.

It should be noted, however, that the area of Bagherabad is about 80 hectares and the neighborhood population was 4220 . The population to be planned for 10 years according to the formula below will be 5044 (Growth Rate 1.8):

$P_{n}=P_{0}(1+r)^{n}$

For example according to studies by the Ministry of Housing and Urban Development, the per capita standard of urban green spaces in Iranian cities is between 7 and 12 square meters per person. This Figure is lower than the benchmark set by the United Nations Environment Agency is 20-25 square meters per person Beiranvand et al. (2013). The per capita in the neighborhood was 4.70 square meters per person, so in the proposed plan we added the extra green spaces so it reached 8.5 square meters per person and it is closer to standard. we have done the same for all other fields (Table 4).

Considering sustainable development, three social centers-a center within the neighborhood and two centers in neighboring areas-are planned to increase social interactions among inhabitants in the neighborhood. Furthermore, the environmental characteristics of the Zarjub Riverside should be improved to be used as a potential area to enhance social interactions in the neighborhood. Also, several plans for promoting shopping, educational, recreational, cultural and economic activities are proposed to utilize abandoned and unused lands (Fig. 3).

Table 4: Available and required spaces for proposal plan

\begin{tabular}{|c|c|c|c|c|c|}
\hline Land use & $\begin{array}{l}\text { Standard per capita } \\
\text { (SQM) }\end{array}$ & $\begin{array}{l}\text { Standard per capita } \\
\text { required (total space) }\end{array}$ & $\begin{array}{l}\text { Current per } \\
\text { capita }\end{array}$ & $\begin{array}{l}\text { Proposed per } \\
\text { capita }\end{array}$ & Shortage of space \\
\hline Residential & 50 & 252200 & 276912 & 387301 & Over the standard \\
\hline Commercial & 8 & 40352 & 66688 & 56660 & Over the standard \\
\hline Educational & 5 & 5044 & 3714 & 5317 & $\begin{array}{l}\text { Closer to standard } \\
\text { (enhanced) }\end{array}$ \\
\hline $\begin{array}{l}\text { Administrative } \\
\text { buildings }\end{array}$ & 2 & 10088 & 46436 & 46436 & For city usage \\
\hline Religious & 0.5 & 2522 & 4346 & 4346 & Over the standard \\
\hline Medical & 0.5 & 2522 & none & 830 & Over the standard \\
\hline Green spaces & $\begin{array}{l}10 \% \text { of available } \\
\text { spaces }\end{array}$ & 80000 & 23695 & 56389 & $\begin{array}{l}\text { Closer to standard } \\
\text { (enhanced) }\end{array}$ \\
\hline Public services & 2 & 5044 & 2276 & 7354 & Over the standard \\
\hline Tourism centre & $\begin{array}{l}2000 \text { SQM for a } \\
4 \text { star hotel }\end{array}$ & 2000 & & 1846 & $\begin{array}{l}\text { Closer to standard } \\
\text { (enhanced) }\end{array}$ \\
\hline Street network & $\begin{array}{l}50 \% \text { of available } \\
\text { Spaces }\end{array}$ & 400000 & 156279 & 32894 & $\begin{array}{l}\text { Closer to standard } \\
\text { (enhanced) }\end{array}$ \\
\hline
\end{tabular}




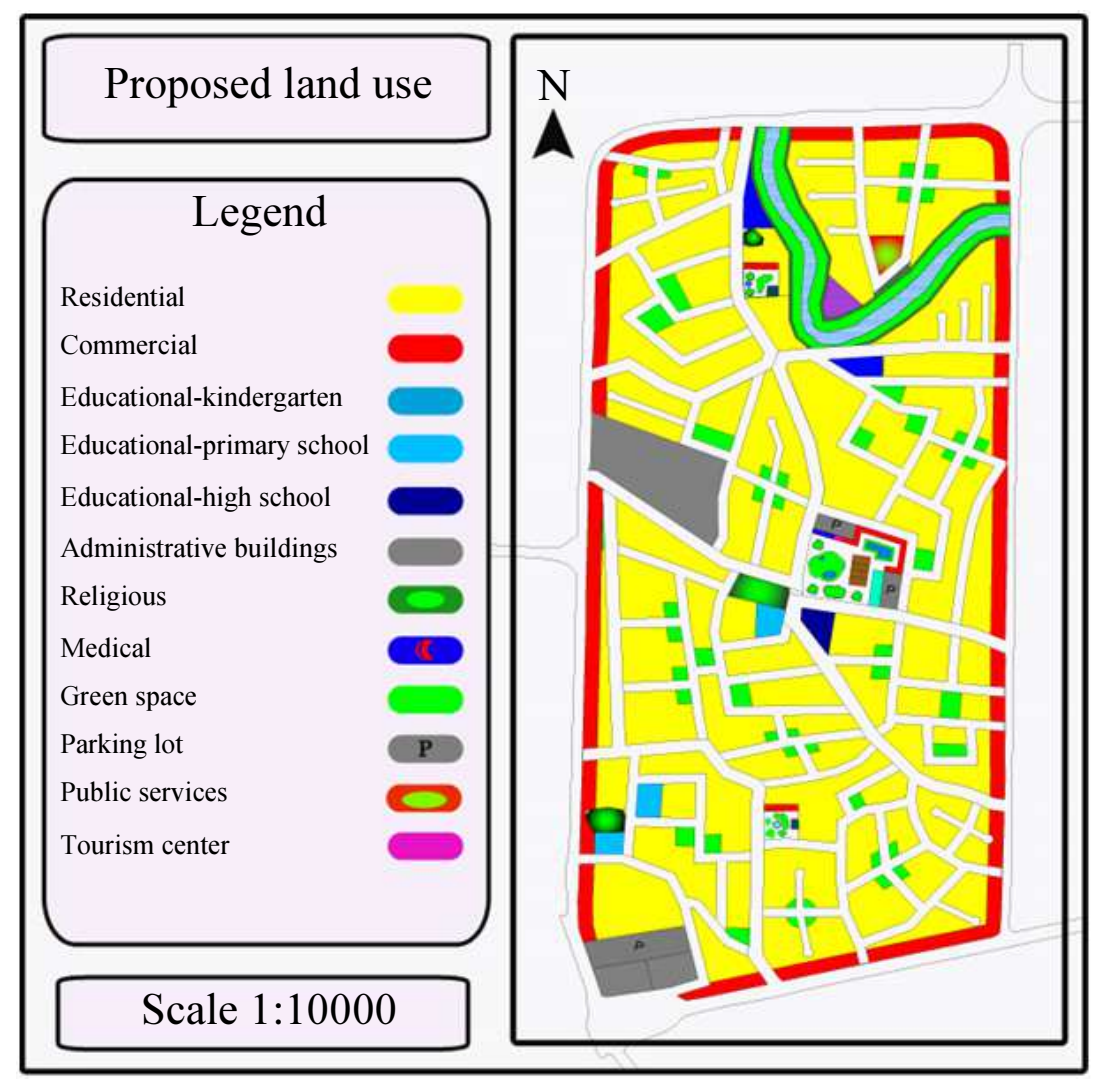

Fig. 3: The proposed land-use plan in the study area

\section{The Proposed Street Network Plan}

Many people in the world have done research on quality of streets as well as designing them. We have done the same with streets and accessibility of spaces and streets, Inspired by their work as well as by the standard per capita in Iran.

Sharifi, (2019) focuses on streets as major constituent elements of urban form. his measures related to urban streets are divided into two broad categories: network topology and design and orientation. It discusses Relationships between urban resilience and different centrality and connectivity measures related to network topology. The design and orientation category explores the possible effects of street width, street edges, street canyon geometry and street layout and orientation on resilience of cities. Appropriate physical form of urban streets can contribute to urban resilience by, among other things, ameliorating urban microclimate, reducing energy consumption and its associated Greenhouse Gas (GHG) emissions, enhancing social capital, improving community health and well-being and facilitating rapid and effective emergency response in the aftermath of disasters.

Sanwei et al. (2019) examines the spatially stratified association between various urban leisure entertainment activities and street con Figurations via a spatial design network analysis and attempts to provide insightful implications for the sustainable development of a city by using a typical inland city of China, Wuhan, as an example. It also says that The street network is characterized by performing a spatial network analysis of the closeness, betweenness, severance and efficiencypara meters. The results indicate that a good street network design can be measured not only by closeness or betweenness but also by severance and efficiency. Four street network metrics are spatially correlated with the locations of leisure entertainment activities. Various types of leisure entertainment activities have distinct locational preferences for street networks (e.g., chess and card rooms favor closeness).

According to the SWOT table, existing standards, predictions for future population growth, density of buildings, traffic, Questionnaire results, as well as expert opinion and the shortage in the street and sideways network and the transportation network we have modified the physical and intellectual dimensions of streets and sidewalks. In some areas, we corrected the width of the streets, sidewalks and passageways between spaces and created safe spaces for pedestrians' cars alongside each other. 


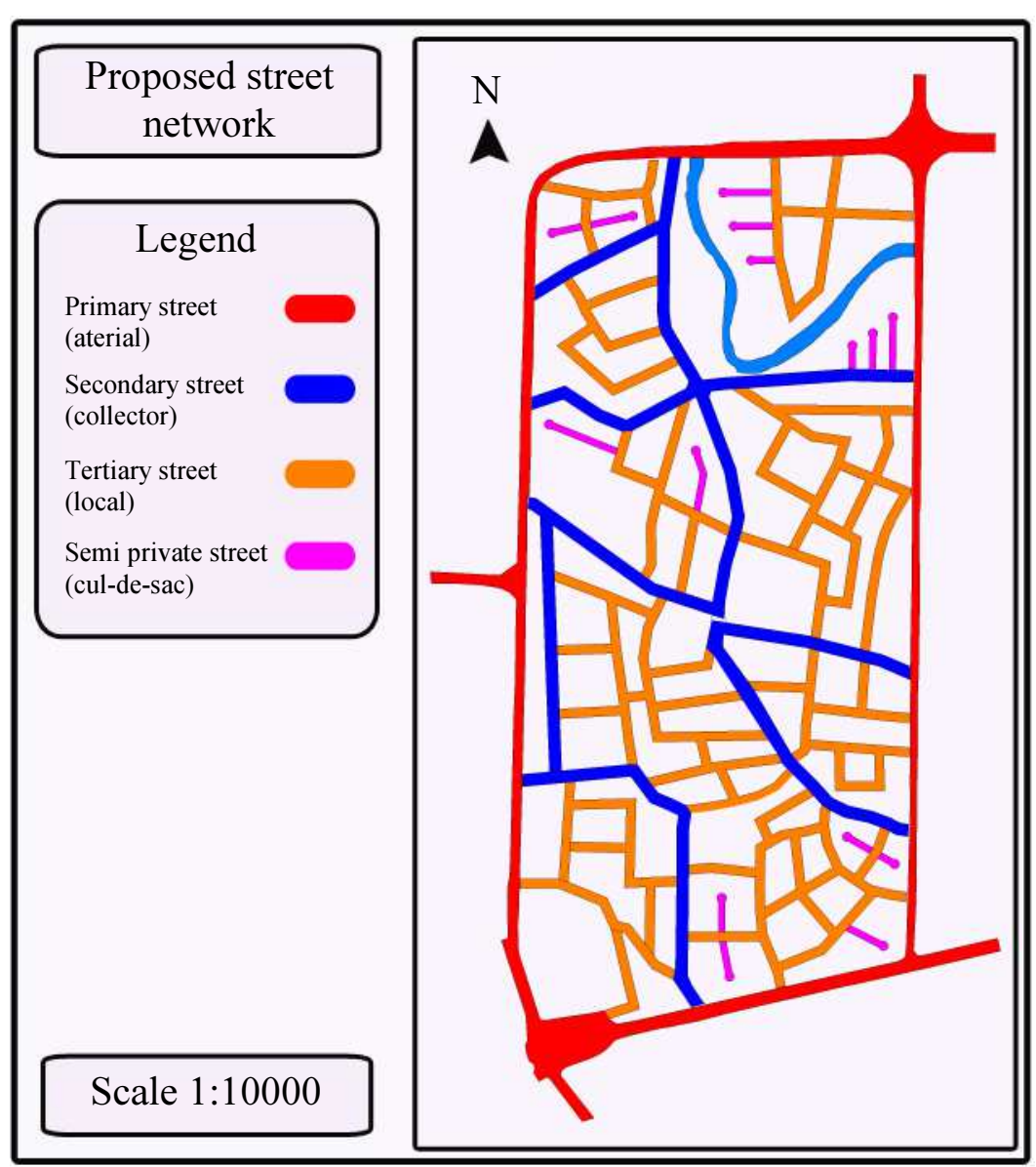

Fig. 4: The proposed street network plan in the study area

As shown in Fig. 4, several measures are proposed to extend and widen the transport network. To enhance walkability and compatibility with the principle of pedestrian-based development in the neighborhood, all streets should have suitable sidewalks. In addition, considering the hierarchy of street network, the accessibility to urban arteries and public transit systems would be improved. By reducing the intersections and conducting some geometric corrections in the street network, traffic and car accidents would considerably decrease and safety increases. Moreover, the vitality and aesthetic characteristics of the environment would increase by developing a variety of green spaces alongside the passageways.

\section{Conclusion}

In this research, we have organized the historical context of Bagherabad that has many different problems through sustainable development approach. Sustainable development is able to provide an exhaustive plan to make this areas suitable and standard places for living of the inhabitants. To do this, we used the questionnaires distributed at the neighborhood to collect the required data, which are the indicators of sustainable neighborhood development. We found that the quality of life indicators in this neighborhood were not as good as it should be. To improve this situation, we used experts' opinion and analyzed data, as well as using SWOT matrix, dependency and independency matrix and considering the standard urban per capita in Iran, we locate the activities using GIS software. We have also improved the accessibility conditions for residents by providing a proposal with the expertise and standard per capita in Iran.

To improve the quality of life, it was proposed that a social center within the neighborhood and two other centers in the neighboring areas to be made, in which residents of the neighborhood would gather around and participate in various social, cultural, recreational activities so that they could meet all their basic needs.

It is expected that this research can be used for similar topics anywhere in the world and we believe that it could have a positive impact on the sustainable development of urban places in neighborhoods and different kind of areas. 


\section{Author's Contributions}

All the authors contributed equally to this prepare, develop and carry out this manuscript.

\section{Ethics}

The authors declare that there are no ethical issues that could arise after the publication of this study.

\section{References}

Andersen, H.S., 2003. Urban sores. On the interaction between segregation, urban decay and deprived neighbourhoods. Danish Building and Urban Research.

Azari, P. and A. Shirzadi Babakan, 2016. Evaluating the ecological capacity for urban development using a combination of AHP and GIS (Case Study: Baghmalek District). J. Environ. Sci. Technol., 18: 173-188.

Babakan, A.S. and M. Taleai, 2015. Impacts of transport development on residence choice of renter households: An agent-based evaluation. Habitat Int., 49: 275-285.

Bahrainy, H. and B. Aminzadeh, 2007. Evaluation of Navab regeneration project in central Tehran, Iran. Int. J. Environ. Res., 1: 114-127.

Barton, H., M. Grant and R. Guise, 2003. Shaping Neighborhoods: A Guide for Health, Sustainability and Vitality. 1st Edn., Taylor and Francis, ISBN-10: 0415260094, pp: 244.

Beiranvand, A., A.E. Bonyad and J. Sousani, 2013. Evaluation of changes in per capita green space through remote sensing data. Int. J. Adv. Biol. Biomed. Res., 1: 321-330.

Botti, A., 2013. Making a sustainable neighbourhood: Gentrification and urban regeneration in Glasgow. Researchgate.com.

Carley, M. and I. Christie, 2017. Managing Sustainable Development. 1st Edn., Earthscan, ISBN-10: 1853834408, pp: 332.

Chapman, D., 2004. creating Neighbourhoods and Places in the Built Environment. 1st Edn., Taylor and Francis, London, ISBN-10: 1135817898, pp: 268.

Cui, J., A. Allan and D. Lin, 2019. SWOT analysis and development strategies for underground pedestrian systems. Tunnel. Underg. Space Technol., 87: 127-133. DOI: 10.1016/j.tust.2018.12.023

Danladi, M.H., M. Rusli Yacob and A. Makmom Abdullah, 2018. Delphi exploration of subjective well-being indicators for strategic urban planning towards sustainable development in Malaysia. J. Urban Manage., 8: 28-41.

DOI: $10.1016 /$ j.jum.2018.08.001
Dyson, R.G., 2004. Strategic development and SWOT analysis at the university of Warwick. Eur. J. Operat. Res., 152: 631-640. DOI: $10.1016 / \mathrm{S} 0377-2217(03) 00062-6$

Farjam, R. and S. Hossieni Motlaq, 2019. Does urban mixed use development approach explain spatial analysis of inner city decay? J. Urban Manage., 8: 245-260. DOI: 10.1016/j.jum.2019.01.003

Frantzeskaki, N., 2019. Seven lessons for planning nature-based solutions in cities. Environ. Sci. Policy, 93: 101-111.

Ghesmi, S.G.A., R. Farhoudi and E. Ezati, 2017. The study of social sustainability in urban renewal process (case of study: District 11 of Mashhad). Int. J. Soc. Sci., 7: 47-65.

Halla, F., 2007. A SWOT analysis of strategic urban development planning: The case of dares salaam city in Tanzania. Habitat Int., 31: 130-142. DOI: 10.1016/j.habitatint.2006.08.001

Hatefi, S.M., 2018. Strategic planning of urban transportation system based on sustainable development dimensions using an integrated SWOT and fuzzy COPRAS approach. Global J. Environ. Sci. Manage., 4: 99-112. DOI: 10.22034/GJESM.2018.04.01.010

Sanwei, H.E., Y.U, Shan., W.E.I. Ping., F.A.N.G. Chuanglin, 2019. A spatial design network analysis of street networks and the locations of leisure entertainment activities: A case study of Wuhan, China. Sustainable Cities Society, 44: 880-887. DOI: $10.1016 /$ j.scs.2018.11.007

Illia Ibrahim, F., D. Omar and N.M. Nik Hanita, 2017. Human interaction in urban spaces: a quantitative analysis in urban park, shah alam city, Selangor. Plann. Malaysia J., 15: 75-84.

Kagan, S., A. Hauerwaas, V. Holz and P. Wedler, 2018. Culture in sustainable urban development: Practices and policies for spaces of possibility and institutional innovations. City Culture Society, 13: 32-45. DOI: 10.1016/j.ccs.2017.09.005

Karimi, F., S. Sultana, A. Shirzadi Babakan and S. Suthaharan, 2019. An enhanced support vector machine model for urban expansion prediction. Comp. Environ. Urban Syst., 75: 61-75.

Khalifipour, H., A. Soffianaian and S. Fakheran, 2012. Application of SWOT analysis in strategic environmental planning: A case study of Isfahan/Iran. Proceedings of the International Conference on Applied Life Sciences, Sep. 10-12, ISALS, Turkey, pp: 123-126.

Li, F., X. Liu, D. Hu, R. Wang and W. Yang, 2009. Measurement indicators and an evaluation approach for assessing urban sustainable development: A case study for China's Jining city. Landscape Urban Plann., 90: 134-142. 
Mahmoud, R.A., 2017. New Cairo's urban dynamics: Redefining gentrification as a main actor of social resilience. Proc. Environ. Sci., 37: 429-441.

DOI: $10.1016 /$ j.proenv.2017.03.013

Matsuoka Rodney, H. and K. Rachel, 2008. People needs in the urban landscape: Analysis of landscape and urban planning contributions. Landscape Urban Plann. , 84: 7-19.

Moroke, T., C. Schoeman and I. Schoeman, 2019. Developing a neighbourhood sustainability assessment model: An approach to sustainable urban development. Sustainable Cities and Society.

Mutisya, E.M., 2016. An assessment of urban decay in residential neighbourhoods: A case study of Jerusalem estate. eastlands, Nairobi. Nairobi: Department of Urban and Regional Planning, School of the Built Environment, University of Nairobi.

Nilsson, M., D. Griggs and M. Visbeck, 2016. Policy: Map the interactions between sustainable development goals. Nature News.

Peres Almeida, C., F. Ramos and J. Silva, 2018. Sustainability assessment of building rehabilitation actions in old urban centres. Sustainable Cities Society, 36: 378-385. DOI: $10.1016 /$ j.scs.2017.10.014

Pobric, A. and G.M. Robinson, 2019. Recent urban development and gentrification in post-Dayton Sarajevo, Bosnia and Herzegovina. Cities, 89: 281-295.

Pourahmad, A., K. Zayyari and J. Zahedi, 2014. The evaluation of urban quality of life by mental approach in afghan immigrants (Case study: Robat Karim City). Geography urban planning research. University of Tehran.
Sharifi, A., 2019. Resilient urban forms: A review of literature on streets and street networks. Build. Environ., 147: 171-187. DOI: 10.1016/j.buildenv.2018.09.040

Shirzadi Babakan, A. and A. Alimohammadi, 2016. An agent-based simulation of residential location choice of tenants in Tehran, Iran. Trans. GIS, 20: 101-125. DOI: $10.1111 /$ tgis. 12144

Shirzadi Babakan, A., A. Alimohammadi and M. Taleai, 2015. An agent-based evaluation of impacts of transport developments on the modal shift in Tehran, Iran. J. Dev. Effectiveness, 7: 230-251. DOI: $10.1080 / 19439342.2014 .994656$

Shirzadi, A., M. Taleai and A. Alimohammadi, 2013. Public transportation mode selection in an urban corridor: Application of multi-criteria decision making methods. Urban-Regi. Studies Res. J., 5: 1-6.

Shoja, H. and M. Heidari, 2015. The role of urban sustainable development and urban sustainable. Natural Social Sci.

Wheeler, S.M., 2004. Planning for Sustainability: Creating Livable, Equitable and Ecological Communities. 1st Edn., Routledge, New York, ISBN-10: 1134351712, pp: 288.

Yigitcanlar, T. and S. Teriman, 2015. Rethinking sustainable urban development: Towards an integrated planning and development process. Int. J. Environ. Sci. Technol., 12: 341-352.

DOI: $10.1007 / \mathrm{s} 13762-013-0491-\mathrm{x}$ 